\title{
The main obstacles for development of international activity with Russian-European chemical clusters: environmental aspect
}

\author{
Dilbar Sultanova ${ }^{1}$, Anna Maliashova ${ }^{1, *}$, Leisan Abzalilova ${ }^{1}$, and Raida Sultanova ${ }^{1}$ \\ ${ }^{1}$ Kazan National Research Technological University, Russian Federation
}

\begin{abstract}
The sustainable development of the continents depends on the uniform progressive development of European and Asian countries. Environmental issues (waste reduction, increasing the share of recyclable waste, the development of plastic recycling industries) are most important. An irresponsible attitude towards waste processing leads to global climatic and natural disasters. The main role is played by the support of global initiatives in the field of plastic waste processing. One of the ways of interaction between countries can be the formation of a cluster policy in the field of waste processing and disposal. The combined efforts of the chemical clusters of Russia and Europe in the face of the common problem of environmental and climate catastrophe can be its solution.
\end{abstract}

\section{Introduction}

The modern world is facing a general environmental disaster, due to the high rate of accumulation of waste from industrial enterprises and the consumer sector. Rapid climate change, as well as the growth of plastic waste around the world, are some of the most talked about topics of the 2020 Davos International Economic Forum.

Today it is impossible to overestimate the contribution of polymer chemistry developers to the development of the industry, but at the same time, the amount of plastic disposed of at landfills leads to global changes in the ecosystem of our planet. The creation of plastic materials was originally intended to replace scarce resources, to ensure safety, comfort, hygiene. Today plastic defines our life and our future. However, in connection with this, at the end of its service life, an acute problem arises of recycling polymer materials. Inadmissible pollution of the oceans with plastic waste is the result of insufficient waste management.

\section{Materials and methods}

In 2018, global plastic production increased to 360 million tons [1]. In European countries, plastics production declined from 64.4 million tons in 2017 to 61.8 million tons in 2018. To date, the distribution of global plastics production is as follows:

- $51 \%$ of all plastic production falls on the countries of Asia, of which $30 \%$ is produced by China, $4 \%$ Japan, $17 \%$ the rest of the countries of the Asian region;

- 18\% North America (NAFTA);

- 17\% European countries;

- $7 \%$ of the countries of the East and Africa;

- 4\% Latin America;
- 3\% of the CIS country [2].

Since 2006, the recycling of plastic waste in Europe has doubled. But, nevertheless, $25 \%$ of it is sent to landfills. Today, Europe is serious about transforming the economy into an even more cyclical and resourceefficient plastics economy.

The European Global Plastics Alliance, which includes 74 plastic associations worldwide, has launched more than 355 projects around the world to solve this problem [2-4]. The collection of plastic waste in 2018 compared with 2016 increased from 27.1 to 29.1 million tons, of which 9.4 million tons of plastic waste were sent for further processing (an increase of 12\%) [3]. Thus, in comparison with 2016, in 2018 there was a decrease in the export of plastic waste outside the European Union by $39 \%$ [4-5].

In 2018, the European Commission launched the European Plastics Strategy for the Circular Economy. The main goals in the plastic industry are:

- all plastic packaging must be recyclable or reusable by 2030

- $50 \%$ of existing plastic packaging waste should be recycled by 2025 ;

- the remaining $50 \%$ of plastic packaging waste should be recycled by 2030 [6-7].

The voluntary agreement to increase the cyclicality and efficiency of the use of plastics resources with global goals sets [8-11]:

- prevention of used plastics from entering the environment (water, soil, air);

- increasing the resource efficiency of plastic products;

- improving the cyclicality of plastic packaging.

Preventive measures should be taken to prevent plastic from entering the environment: timely detection, prevention of clogging, and prevention of loss of raw materials.

\footnotetext{
"Corresponding author: annamalyashova@gmail.com
} 
Improving the resource efficiency and cyclicality of plastic products can be achieved by researching alternative sources of raw materials, updating and expanding the collection of waste data, developing ecological design of plastic packaging, and supporting new standards in the field of plasticity of plastics. An important point is the change in the culture of consumption by the world's population in the direction of increasing personal responsibility for the separate collection of garbage, a conscious choice in favor of the reuse of things made of plastic materials, and the prevention of plastic products from entering the environment (landfills, etc.).

A main role is played by the support of global initiatives in the field of plastic waste processing.

\section{Results}

The sustainable development of the continents depends on the uniform progressive development of both European countries and Asian countries. Environmental issues (waste reduction, increasing the share of recyclable waste, the development of plastic recycling industries) are critical. An irresponsible attitude towards waste processing leads to global climatic and natural disasters. In this regard, it is important and relevant to determine the development path of sustainable development policies and the circular economy in the countries that are leaders in this movement and the formation of an algorithm for intensifying activities in countries where waste management issues are not given due attention.

Studying the statistics of the EU countries on the volumes and forms of waste processing, you can see a high differentiation (table 1). [12]
Table 1.

\begin{tabular}{|c|c|c|c|}
\hline Country & $\begin{array}{c}\text { Plastics } \\
\text { processing, } \\
\text { \% of total } \\
\text { waste }\end{array}$ & $\begin{array}{c}\text { Recycling } \\
\text { rate of } \\
\text { municipal } \\
\text { waste, \% }\end{array}$ & $\begin{array}{c}\text { Waste } \\
\text { treatment, } \\
\text { including } \\
\text { incineration, } \\
\text { \% of total } \\
\text { waste }\end{array}$ \\
\hline Austria & 22 & 57.7 & 99 \\
\hline Belgium & 32 & 54.6 & 97.5 \\
\hline Bulgaria & 19 & 36.8 & 25.5 \\
\hline Germany & 38 & 67.3 & 98.5 \\
\hline Great & 32 & 43.8 & 70 \\
\hline Britain & 21.5 & 37.4 & 43 \\
\hline Hungary & 35 & 47.9 & 97.5 \\
\hline Denmark & 20 & 18.9 & 21.5 \\
\hline Greece & 28.5 & 49.8 & 62.5 \\
\hline Italy & 38 & 40.4 & 89 \\
\hline Ireland & 36 & 36 & 53 \\
\hline Spain & 30 & 25.2 & 31.5 \\
\hline Latvia & 30 & 50.1 & 97.5 \\
\hline Luxembourg & 22 & 16.1 & 24 \\
\hline Cyprus & 18.5 & 6.5 & 18.5 \\
\hline Malta & 24 & 52.2 & 51.5 \\
\hline Lithuania & 32 & 28.9 & 63 \\
\hline Portugal & 32 & 55.9 & 98.5 \\
\hline Netherlands & 22 & 11.1 & 36 \\
\hline Romania & 27 & 34.3 & 55.5 \\
\hline Poland & 30 & 36.3 & 53.5 \\
\hline Slovakia & 30.5 & 58.9 & 71 \\
\hline Slovenia & 22 & 44 & 66 \\
\hline France & 21 & 42.3 & 92 \\
\hline Finland & 28 & 78 \\
\hline Estonia & 33 & 34.5 & 59.5 \\
\hline Czech Rep. & 38 & 45.8 & 98.5 \\
\hline Sweden & 40.5 & & \\
\hline & & & \\
\hline
\end{tabular}

The objective of this stage of the study is to identify factors that have a significant impact on the pace of development of waste management policies and the circular economy.

If one look at the statistics presented in table 1, at first glance it seems that the leaders in implementing waste management policies are Sweden, Austria, Germany and the Netherlands. However, judging by this indicator is short-sighted. It is important to highlight the share of high-tech processes in the total volume of recyclable waste. Obviously, the separation of plastics before falling into general waste contributes to the growth of plastic recycling industries. These technologies are not limited to mechanical grinding and incorporation into the production process for recycling. Leaders of the world machine tool industry in the field of polymer processing are now paying much more attention to chemical recycling technologies. In this case, as a result of a chemical reaction, polymers decompose into monomers, which allows them to produce high-quality products during repeated polymerization.

Thus, as a criterion for the effectiveness of the waste management policy at the first stage of the study, we chose the indicator $\mathrm{y}_{1}(\mathrm{x})$ the share of plastic recycling, at the second stage of the study, $\mathrm{y}_{2}(\mathrm{x})$ the indicator of municipal waste processing performed and at the third stage the influence of factors on $\mathrm{y}_{3}(\mathrm{x})$ the total indicator 
of the share of plastic recycling and waste disposal through incineration in incinerators of the total waste.

The following factors were selected as factors influencing the effectiveness of this policy: area per 1 inhabitant of GDP per capita, R\&D expenses, business activity index, human capital index, labor productivity.

The following hypotheses were to be tested:

H1 the smaller the area, the less the possibility of burial, the more the government is concerned about the development of waste processing;

$\mathrm{H} 2$, the higher the country's GDP, the more attention is paid to waste processing;

$\mathrm{H} 3$ the higher the cost of $\mathrm{R} \& \mathrm{D}$, the more available technologies for the recycling of polymers;

$\mathrm{H} 4$ the higher the human capital index, the more socially active the population is in the issues of separate collection of garbage and its further recycling;

$\mathrm{H} 5$ the higher the labor productivity in the country, the more attention is paid to waste, as to the resources of further increasing the efficiency of the regional economy, in terms of Lean management.

At the next stage, we built regression models based on data from $28 \mathrm{EU}$ countries. The significance of the obtained coefficients was checked by the student ratio equal to 2.048 with the number of degrees of freedom of 27. When constructing the first model reflecting the degree of development of plastic waste processing, none of the five factors that we identified were significant. Obviously, the degree of development of polymer recycling is significantly affected by other factors that were not taken into account by us during this stage of the study.

The model of municipal waste processing level has the following form.

$$
Y_{2}(x)=19,25085 X_{1}+3,248271 X_{2}
$$

where $\mathrm{X}_{1}$ is R\&D Cost, \% of GDP; $\mathrm{X}_{2}$ - Human Capital Index.

The model of the share of plastics recycling and waste disposal through incineration in waste incinerators of the total waste volume also showed a dependence on R\&D investments.

$$
y_{2}(x)=9,661338605 X_{1}
$$

The remaining indicators introduced into the model did not have a significant effect on the resulting parameter.

\section{Discussion}

The analysis allowed us to identify interesting patterns. So, the level of municipal waste processing is significantly affected by the human capital development index. This indicator takes into account life expectancy, the level of education of the population and the standard of living of the population. Thus, the higher the level of social development of a country, the easier it is to organize separate collection of garbage and processing of municipal waste.
As our calculations showed, investments in $R \& D$ have the greatest impact on the development of recycling. This indicator turned out to be significant in two models. This is due to the fact that plastic recycling, chemical recycling and pyrolysis of waste are quite complex technological processes, which necessitate the training of personnel and the necessary infrastructure for the large-scale implementation of waste management. Therefore, developing countries that are at the start of the formation of a new environmental policy focused on building closed-loop economic models should take this into account and actively introduce the experience of the leading European countries.

As for Russia, today we can say that a clear understanding of the principles of the cyclical economy of polymer materials among manufacturers and processors has not been formed. However, there is an understanding that we must connect to the global process of reducing polymer waste. The Ecology national project encompasses a solid waste management program that will be co-financed by Russian business. Under this program, approximately 30 million tons of waste will be processed annually and another 20 million tons will be disposed of. There are examples of businesses such as Sibur, which joined Operation Clean Sweep as part of the Plastic Europe Association of European Plastic Product Manufacturers. The initiative aims to minimize the loss of polymer particles during production and logistics processes. In Sibur, this happens at enterprises in Perm and Tobolsk. [13-15] Enterprises of the polymer industry set the task of including waste-free production into the process and transitioning to a circular economy.

But this process is encountering many obstacles.

The main reasons are a lack of understanding of the transition mechanisms and the lack of the possibility of readjusting outdated technological processes due to poor motivation. Since the beginning of 2019, a new waste management system has been operating in Russia: there are still some difficulties, but many market participants are confident that there will be a further development of the polymer recycling segment [16]. According to the forecasts of the Ministry of Natural Resources of the Russian Federation, by 2024 the level of waste sorting can be $60 \%$, and the level of recycling - 36\% [17].

At the moment, the sphere of waste management in the Russian Federation is still at the formation stage: 5\% of waste is sent for recycling, $10 \%$ to landfills that meet environmental requirements, $85 \%$ go to facilities that do not ensure environmental safety. The main problems remain unresolved. Among them are waste disposal at unauthorized landfills and the lack of a sufficient number of waste management facilities. In the segment of polymer recycling, there is a lack of sorting and processing facilities, a fragmented market, and an underdeveloped separate collection system. [18]

\section{Conclusion}

Thus, the study shows the need for cooperation between the countries of the European Union and developing countries in the fight against waste. One of the ways of 
interaction can be the formation of a cluster policy in the field of waste processing and disposal. The combined efforts of the chemical clusters of Russia and Europe in the face of the common problem of environmental and climate catastrophe can be its solution.

Today in the Russian Federation, cluster development policy is developing. Six large polymer clusters are being successfully formed nationwide with examples: 1) in Western Siberia on the basis of the ZapSibNeftekhim production complex, 2) in the Volga region on the basis of dozens of existing polymer complexes and tens of thousands of plants for their processing, and 3) in the North-West of the country on the basis of the complexes under construction in the region of the seaport of Ust-Luga. It is very important that the principles of the circular economy be laid in the foundation of sustainable development of the territories where polymer clusters are located. The development of new effective solutions for the circular economy is also envisaged in world-class scientific and educational centers created with state support. In Russia, 15 such centers will be created by 2024 [19-20].

The Republic of Tatarstan is one of the leading regions of the Russian Federation with a high level of development of industries for the production and processing of polymer materials. Enterprises are included in the global agenda of the circular economy, setting tasks within polymer clusters for scientific organizations in the search and development of new technologies for the production of polymer composite materials to ensure their reuse. Educational programs are being developed that involve most of the region's population (schoolchildren, students, households) in a closed-loop economy. Ecological initiatives are being implemented in the region that are changing people's attitudes to the problem of accumulation and qualified waste management. Recycling plastic waste collection points have been established in large cities (PET, PP, PS, PE, etc.). Pupils and students are involved in the initiatives of enterprises and educational institutions to find ways to process unused polymer materials. Cluster initiatives are being implemented for the comprehensive utilization of trucks, household appliances, lead batteries, etc. In order to disseminate experience and adopt the best foreign practices, it is important to ensure a stable connection between Russian polymer clusters and the international community.

Today, there are a number of barriers to effective cooperation between the Russian Federation and the European Union in matters of a circular economy. Among them, the presence of competition factors for the main sales markets, which complicates the communication process between direct competitors; different levels of scientific and technological development of industries in countries; the presence of language, cultural and mental barriers that worsen interpersonal communication.

For the formation of an ecological worldview within the framework of cluster interaction, a continuous exchange of accumulated experience, both best practices and unsuccessful attempts, is necessary. It is advisable to invite the heads of chemical enterprises, municipal authorities, young scientists of Russia to European countries to acquire new knowledge and experience in the field of waste recycling and disposal, as well as to jointly discuss and develop effective solutions within the framework of communication platforms. In October 2020, Kazan will host the TCI Network 2020 World Cluster Conference, where it is planned to pay special attention to circular economy issues. This platform can become a place for building international cooperation on circular economy issues among clusters around the world.

It is necessary to form sustainable partnerships in the form of joint initiatives, joint $R \& D$, joint cluster projects, entry into existing partner networks and the formation of new consortia to solve this global problem. This is an area where competition issues should go by the wayside, and intellectual and managerial efforts should be combined in the face of the challenge of preserving the planet's ecological system.

\section{References}

[1] K 2019: PlasticsEurope unveils updated plastics data and Voluntary Commitment progress, Plastics Europe AISBL Press Release Düsseldorf, (17 October 2019).

[2] Plastics Europe, Press Release, Dusseldorf (17 October 2019).

[3] Plastics - the Facts 2019, An analysis of European plastics production, demand and waste data, Brussels, Belgium (2019).

[4] Plastics - the Facts 2017, An analysis of European plastics production, demand and waste data, Brussels, Belgium (2017)

[5] Plastics - the Facts 2018 An analysis of European plastics production, demand and waste data, Brussels, Belgium (2018).

[6] K 2019: PlasticsEurope unveils updated plastics data and Voluntary Commitment progress [Electronic resource]. Available at: https:/pr.euractiv.com/pr/k-2019-plasticseuropeunveils-updated-plastics-data-and-voluntarycommitment-progress-195488.

[7] Martin WIesweg, PS \& PET Sustainability Impact (18 October 2019).

[8] Plastics 2030, PlasticsEurope's Voluntary Commitment to increasing circularity and resource efficiency, Brussels, Belgium (2019).

[9] The circular economy for plastics, A European overview, Plastics Europe, Brussels, Belgium (2019).

[10] P. Ghisellini, C. Cialani, S. Ulgiati, review on circular economy: The expected transition to a balanced interplay of environmental and economic systems, Journal of cleaner production, 7 (114), 11 32 (2016).

[11] Industrial waste in Europe [Electronic resource]. Available at: https://www.eea.europa.eu/data-andmaps/indicators/industrial-waste-indicator/ assessment-1. 
[12] Production and international trade in chemicals [Electronic resource]. Available at: https://ec.europa.eu/eurostat/statistics-explained/ index.php/.

[13] S. Sakai, J. Yano, Y. Hirai, et al., Waste prevention for sustainable resource and waste management, Journal of material cycles and waste management, 19, 1295-1313 (2017).

[14] Recycling polymers, Sibur mag., 14 (2019) [Electronic resource]. Available at: http://magazine.sibur.ru/en/article/focus/interplastic a-2019/.

[15] Interplastica 2019, Sibur mag., 14 (2019).

[16] INVENTRA: polymer recycling in Russia, Plastinfo mag. (13 March 2019) [Electronic resource]. Available at: https://plastinfo.ru/information/articles/682/.

[17] A.V. Volkova, Disposal market waste, Nat. Res. Un., High School of Ec., Development Center (2018).

[18] On the development plan for gas and petrochemicals of the Russian Federation for the period until 2030 [Electronic resource]. Available at: http://docs.cntd.ru/document/499072050.

[19] World-class research and educational centers [Electronic resource]. Available at: http://minobrnauki.gov.ru/ru/activity/act/dgnintp/na uka/notc/.

[20] L. Abzalilova, Conditions for intensifying foreign economic activity of chemical enterprises, Materials of the International Conference "Process Management and Scientific Developments", Birmingham, United Kingdom, 26-34 (14 November 2019). 